\title{
Triatoma Williami Galvão, Souza e Lima, 1965 (Hemiptera, Triatominae) in Intradomiciliary Environments of Urban Area in Mato Grosso State, Brazil Domiciliation Process of a Wild Species?
}

\section{Mirian Francisca Martins ( $\nabla$ mirianfranmartins@gmail.com )}

Secretaria de Estado de Saúde de Mato Grosso do Sul: Secretaria de Estado de Saude de Mato Grosso do Sul https://orcid.org/0000-0001-6288-7995

\section{Sinara Cristina de Moraes}

Secretaria de Estado de Saúde de Mato Grosso do Sul: Secretaria de Estado de Saude de Mato Grosso do Sul

Jader Oliveira

Universidade de São Paulo: Universidade de Sao Paulo

Janaina Cipriana dos Santos

Universidade Federal de Mato Grosso

\section{Ludier Kesser Santos-Silva}

Universidade Federal de Mato Grosso

\section{Cleber Galvão}

Laboratório Nacional e Internacional de Referência em Triatomíneos, Instituto Oswaldo Cruz- Fiocruz

\section{Research Article}

Keywords: Triatominae, Triatoma williami, colonization, Trypanosoma cruzi, Chagas disease, surveillance programs

Posted Date: August 30th, 2021

DOI: https://doi.org/10.21203/rs.3.rs-844384/v1

License: (c) (1) This work is licensed under a Creative Commons Attribution 4.0 International License. Read Full License 


\section{Abstract}

Background: Triatomines found throughout Latin America are natural Chagas disease vectors (ChD). The domiciliation of triatomines is one of the main factors increasing the occurrence risk of human cases of this disease. There are 66 species of triatomine in Brazil, with three genera of significant epidemiological importance: Panstrongylus, Rhodnius, and Triatoma. Among the Triatoma species, Triatoma williami, a wild species, has been reported in the Brazilian states of Goiás, Mato Grosso, and Mato Grosso do Sul. In the city of Barra do Garças, Mato Grosso, the invasion by triatomines has been reported, with $T$. williami being the most common species.

Methods: Triatomine specimens were collected by passive surveillance or by active search by agents combating endemic diseases. After taxonomic identification, a parasitological feces diagnosis was performed to detect the presence of Trypanosoma cruzi. Concerning T. cruzi identification, molecular diagnosis and genetic sequencing were performed to identify the strain, also called discrete typing units (DTUs).

Results: In 2019, several triatomine specimens were collected in the urban area of Barra do Garças, Mato Grosso. Among them, 155 specimens were T. williami, P. geniculatus, and R. neglectus. In 2020, the sampled triatomine specimens were 56 T. williami, Panstrongylus diasi, and $R$. neglectus. For these years, T. williami has been the most frequent species. Between 2019 and 2020, 137 T. williami were collected (61\% of them inside houses). In two triatomine colonies were found and morphological analyses, indicated were T. williami. These insects were collected inside houses in an urban area, on a neighborhood from Jardim Pitaluga ( $\left.15^{\circ} 51^{\prime} 57.7^{\prime \prime} \mathrm{N}, 052^{\circ} 16^{\prime} 04.5 \mathrm{E}\right)$. The records were sampled in September/2019 and January/2021. The rate of natural infection was $30.3 \%$ and $73.5 \%$ for 2019 to 2020. Two T. williami specimens belonging to one of colonies were positive for T. cruzi strain DTU IV,

Conclusions: This is the first time that the occurrence of domiciliation of T. williami has been confirmed in an urban area of Barra do Garças, Mato Grosso, Brazil. Further studies are needed for a clearer understanding of the ecology of this species for prevention and control mechanisms, since its sampled specimens had a high rate of natural infection by $T$. cruzi.

\section{Introduction}

The blood-sucking insects of the Triatominae subfamily are vectors of Chagas disease (ChD), an infection caused by the protozoan Trypanosoma cruzi (Chagas, 1909). The subfamily comprises 154 extant and three fossil species within five tribes and 18 genera (GALVÃO et al. 2020). In Brazil, 66 triatomine species have been previously recorded (GALVÃO, 2014; SOUZA et al., 2016; ALEVI et al., 2020; ZHAO et al., 2021).

Three genera have special significant sanitary importance and are related to the transmission of $T$. cruzi to humans: Panstrongylus Berg, 1879, Rhodnius Stål, 1859 and Triatoma Laporte, 1832 (GALVÃO et al., 2014; MONTEIRO et al., 2018; MS, 2015; OLIVEIRA and ALEVI, 2017; SILVA et al., 2015). 
Vectorial transmission by Triatoma infestans (Klug, 1834) was officially eliminated from Brazil in 2006 representing the enormous efforts to halt the transmission of ChD by non-native vectors (ABAD-FRANCH et al., 2013). Despite this significant achievement, this "certification" may give a false idea that the disease transmission does not exist (BRANDÃO et al., 2015). However, native triatomine species are potential vectors of $T$. cruzi and can invade and colonize artificial environments (VINHAES et al., 2014). The domiciliation of triatomines is one of the main factors in the increasing transmission risk of $T$. cruzi to humans (LENT AND WYGODZINSKY, 1979). Anthropogenic morphoclimatic alterations propel the domiciliation process and dispersal of triatomines and can be interpreted as a survival strategy for the species (Forattini 1980). Silveira (2000) reported that the domiciliation process results from factors that may promote the invasion and progressive adaptation of triatomines to human households and may be related to the environment and the characteristics inherent in the vector. The domiciliation could be accelerated by the opportunism of wild triatomine species in the scenario of natural food sources scarcity. The human demographic shift is partially responsible for the changes in vectorial transmission. Such a shift promoted unfavorable environmental changes and subsequent rarefaction in wild fauna, leading triatomines to move to highly stable artificial habitats that offer a variety of hiding places and an abundance of food throughout the year (WHO, 2002).

The trends toward domesticity seem to be associated with behavioral plasticity (Carbajal de la Fuente et al. 2008), reducing the genetic repertoire of specimens, and increasing developmental instability. These conditions make triatomine species/populations more efficient vectors.

For a long time, Triatomine species have been classified according to their adaptation to human dwellings. Such a classification usually occurs in three groups, with Triatomine species classified as domiciliary, peridomiciliary, and wild. Noireau and Dujardin (2010) proposed four categories: sylvatic, intrusive, domiciliary, and domestic species. Such definitions have been the most widely accepted and are used in the literature to classify many triatomine species (WALECKYX et al., 2015).

From the vector control perspective, it is of significant importance to precisely determine three aspects of the relationship between triatomines and humans: (i) the prevalence of sylvatic populations of triatomines, (ii) the level of intrusion of these sylvatic populations in peridomiciles and inside domiciles, and (i) the level of domiciliation or domestication in peridomiciles and houses (WALECKYX et al., 2015). Nowadays, the attention is focused on the domiciliation of species, which were, until then, considered sylvatic because of increasing reports of wild species invading human and peridomestic dwellings in South American countries (GALVÃO et al., 2001; SOTO-VIVAS et al., 2001; VALENTE, 1999). In the last few decades, the literature has reported invasions by at least 10 species, increasing the risk of intradomiciliary colonies in Brazil, Bolivia, Colombia, and Venezuela (Table 1).

Triatoma williami Galvão, Souza e Lima, 1965 is a wild species that has been reported in the Brazilian states of Goiás, Mato Grosso, and Mato Grosso do Sul (ALMEIDA et al 2008; ARRAIS-SILVA et al., 2011, GALVÃO 2014). The risk of domiciliation of this species was previously hypothesized by Andrade-Neto et 
al. (2012) through interviews with residents. Here, the domiciliation of this species was demonstrated through observing all of its life stages, including eggs, within a human dwelling.

Table 1

Species of triatomines already recorded to be domiciliated in human dwellings.

\begin{tabular}{|lll|}
\hline Specie & City/State/Country & Reference \\
\hline Panstrongylus megistus & São Paulo, Brazil & Silva et al. (2021) \\
\hline P. rufotuberculatus & La Gardenia, Colombia & $\begin{array}{l}\text { Wolf and Castillo (2002) Depickère et } \\
\text { al. (2011) }\end{array}$ \\
\hline P. geniculatus & Munecas, La Paz, Bolivia & $\begin{array}{l}\text { Reyes-Lugo and Rodriguez-Acosta, } \\
\text { (2000) }\end{array}$ \\
\hline Rhodnius stali & Alto Bebi, Bolivia & Matias et al. (2003) \\
\hline $\begin{array}{l}\text { Triatoma brasiliensis } \\
\text { macromelasoma }\end{array}$ & $\begin{array}{l}\text { São João do Piauí, Piauí, } \\
\text { Brazil }\end{array}$ & $\begin{array}{l}\text { Santos et al. (2017) } \\
\text { T. rubrovaria }\end{array}$ \\
\hline T. maculata & Rio Grande do Sul, Brazil & Almeida et al. (2000) CEVS/RS (2009) \\
\hline Pitahaya, Venezuela & $\begin{array}{l}\text { Reyes-Lugo and Reyes-Contreras } \\
\text { (2011) }\end{array}$ \\
\hline T. nigromaculata & Boa Vista, RO, Brazil & Luitgards-Moura (2005) \\
\hline T. pseudomaculata & Ricardo-Silva et al. (2016) \\
\hline T. sherlocki & Merida, Venezuela & Añez et al. (2005) \\
\hline
\end{tabular}

\section{Material And Methods}

The municipality of Barra do Garças, in the state of Mato Grosso, has a population of 56,423 inhabitants and a territorial area of $9,079 \mathrm{~km}^{2}$ (IBGE 2017) (Fig. 1). It is located at the margins of the Garças and Araguaia rivers, forming an essential touristic complex. The biome is the Brazilian Cerrado, characterized by spatial heterogeneity and high endemism of plants and insects (MMA 2002; SILVA AND BATES, 2002), and is considered a biodiversity hotspot. The climate of this region is characterized by two seasons, dry winter and rainy summer, and corresponds to the Aw climatic type, according to Köppen's classification (KÖPPEN, 1948). The climate of this region has an annual average humidity of $60 \%$ and an annual average temperature of $20-27^{\circ} \mathrm{C}$.

The headquarters of the municipality is organized in 53 neighborhoods. The city health secretariat (Secretaria Municipal de Saúde) has 45 endemic control field agents to perform health surveillance and vector control activities. Three of these agents work in the surveillance and control of ChD vectors. 
The inhabitants usually collect the triatomines found in the human dwellings. These people inform the health workers or deliver the specimens directly to the Entomology Laboratory at the Regional Health Office of Barra do Garças (ERSBG abbreviation in Portuguese) from the State Health Secretariat of Mato Grosso (SESMT abbreviation in Portuguese), Brazil. All of the sampled material was analyzed in this facility. The identification of the specimens was made through the use of dichotomous keys from Lent and Wygodzinsky (1979) and Galvão (2014). The identification of these insects as T. williami was carried out based on the external morphological characteristics of the head, wing, abdomen, and external female genitalia (Fig. 2A-E). Such analyses confirmed the importance of these structures, as previously discussed by Teves et al. (2020). Based on this information, the activities of the ChD surveillance team are triggered.

For the analysis of natural infection by $T$. cruzi, the conventional polymerase chain reaction (CPCR) was performed as previously described by Brígido, et al (2017) using oligonucleotides P21 fw (5'AACGCACCATCAATCTTTTG-3') and P21 rv (5'-CGTCGCATTCCTCATTTCTTC-3') that amplify a 65bp fragment from the genomic region of the parasite. For T. cruzi DTUs identification, CPCR was performed according to Cosentino and Agüero (2012) using the oligonucleotides TcSC5D-forward 5'GGACGTGGCGTTTGATTTAT-3' and TCSC5D-reverse 5'-TCCCATCTTCTTCGTTGACT-3' that produce a amplicon of 832bp from TcSC5D gene. The amplicons were sequenced at ABI3730xI Genetic Analyzer (Applied Biosystems). The sequences of the T. cruzi TcSC5D gene were analyzed on Clustal Omega tool (Sievers and Higgins, 2014) to discriminate the DTUs Tcl to TcVI using the polymorphic sites described by Cosentino and Agüero (2012).

\section{Results}

The invasion of wild triatomines has been reported in urban housing units from the municipality of Barra do Garças, Mato Grosso, Brazil, and a ten-year historical series confirmed it. During this series, the species collected were: Triatoma williami Galvão, Souza and Lima (1965), Panstrongylus diasi Pinto \& Lent 1946, Panstrongylus geniculatus (Latreille, 1811), and Rhodnius neglectus Lent, 1954.

In 2019, 155 specimens of T. williami, P. geniculatus, and R. neglectus were collected. In 2020, 56 specimens of T. williami, P. diasi, and R. neglectus were collected. During all of the analyzed years, $T$. williami was the most frequent species (Fig. 3).

In the urban area of Barra do Garças, Mato Grosso, Brazil, the presence of T. williami has been registered in eight neighborhoods. In 2019 and 2020 (Table 2), the highest infestation recorded were found at boundaries of the Serra Azul State Park (PESA abbreviation in Portuguese) (Fig. 4). 
Table 2

Distribution of the collected Triatoma williami specimens by neighborhood in Barra do Garças, Mato Grosso, Brazil, in 2019 and 2020.

\begin{tabular}{|lllll|}
\hline T. williami abundance by neighborhood & $\mathbf{2 0 1 9}$ & \multicolumn{3}{l}{2020} \\
\cline { 2 - 5 } & AF & RF (\%) & AF & RF (\%) \\
\hline Jd Amazônia I - BNH & 57 & 41.6 & 32 & 78.0 \\
\hline Jd Pitaluga & 72 & 52.6 & 9 & 22.0 \\
\hline Jd Araguaia & 2 & 1.5 & 0 & 0.0 \\
\hline Santo Antônio & 2 & 1.5 & 0 & 0.0 \\
\hline Monte Sinai & 1 & 0.7 & 0 & 0.0 \\
\hline Jd Amazônia II & 1 & 0.7 & 0 & 0.0 \\
\hline Jd Piracema & 1 & 0.7 & 0 & 0.0 \\
\hline São Sebastião & 1 & 0.7 & 0 & 0.0 \\
\hline Total & $\mathbf{1 3 7}$ & $\mathbf{1 0 0 . 0}$ & $\mathbf{4 1}$ & $\mathbf{1 0 0 . 0}$ \\
\hline AF: Absolute frequency; RF: Relative frequency. & & & \\
\hline
\end{tabular}

For T. williami, the number of females collected was larger than that of the males. During 2019 and 2020, the females/males ratio was not within the expected 1:1 pattern. It was 0.79 in 2019 and 0.75 in 2020 (Fig. 5).

From 2019 to 2020, 137 specimens of $T$. williami were collected, with $61 \%$ found inside houses. In 102 of these locations, these specimens were found in the three common environments in which they usually occur: indoor, peridomicile and no information (Fig. 6).

From a monthly density analysis of the sampled triatomines from 2019 to 2020 , it is possible to observe that environmental seasonality was more significant during the third quarter of the year. This period is recorded as the driest climatic season in the region (Fig. 7)

In 2019, three species of triatomines, from three significant genera to the epidemiological context of ChD, were naturally infected by $T$. cruzi in the urban area of Barra do Garças: T. williami, P. geniculatus, and $R$. neglectus. In 2020, specimens from the species $T$. williami, $R$. neglectus, and $P$. diasi were positively infected with T. cruzi. From 2019 to 2020, of the 155 and 56 triatomines collected and analyzed, 90 and 42 had a parasitological diagnosis for $T$. cruzi infection, respectively. 
Table 3

The rate of natural infection analysis for Trypanosoma cruzi in triatomines collected in Barra do Garças, Mato Grosso, Brazil, for 2019 to 2020.

\begin{tabular}{|llllllll|}
\hline & 2019 & \multicolumn{7}{c|}{2020} \\
\hline $\begin{array}{l}\text { Species/ } \\
\text { Infection rate }\end{array}$ & Analyzed & Positive & Infection rate & Analyzed & Positive & Infection rate \\
\hline Triatoma williami & 76 & 23 & 30.3 & 34 & 25 & 73.5 \\
\hline Rhodnius neglectus & 12 & 1 & 8.3 & 4 & 1 & 25.0 \\
\hline Panstrongylus diasi & 0 & 0 & 0.0 & 3 & 1 & 33.3 \\
\hline $\begin{array}{l}\text { P. geniculatus } \\
\text { Total }\end{array}$ & 2 & 1 & 50.0 & 1 & 0 & 0.0 \\
\hline $\begin{array}{l}\text { Source: Data recorded in the monthly sheet of the ChD Control Program, State Health Secretariat of } \\
\text { Mato Grosso, Brazil. }\end{array}$ & 90 & 25 & - & & & \\
\hline
\end{tabular}

In September 2019, the ChD surveillance team attended to a request from the resident and went to that human dwelling to carry out an entomological survey for triatomines. After one bed was searched, the field agents found adult specimens, eggs, and nymphs on the wooden bed frame (Fig. 8A-C). Signs of feces were also observed. These findings were the first evidence of colonization of $T$. williami, which was also characterized by four sampled adults (one male and three female), 41 nymphs in the first developmental stage, and 34 eggs (Fig. 9A-B).

After these triatomines were found, the endemic control agents of the City Health Secretariat of Barra do Garças performed a residual chemical control in that house. In 2020 the agents did not carry out entomological research and chemical control in this house.

In January 2021, more specimens were caught inside human dwellings by the residents. These specimens were handed over to the ERSBG from the SESMT. This was the second record of compound domiciliation with eight sampled specimens: two males, one female, and five nymphs (one nymph in the $\mathrm{N} 1$, one in the N2, two in the N4, and one in the N5 stages).

In February 2021, the field agents carried out residual chemical control in the infested house again. In June 2021, the resident on that infested house collected and delivered two additional T. williami nymphs to the ERSBG from the SESMT: one nymph in the N1 stage, one dead male, and one exuviae (Fig. 10).

Both colonies of $T$. williami were found indoors, in beds, in an urban area on the neighborhood Jardim Pitaluga (S15 51'57.7" W052 16'04.5) in Barra do Garças, Mato Grosso, Brazil. The voucher specimens from the first colony were deposited in the Herman Lent Collection of the Instituto Oswaldo Cruz in Rio de 
Janeiro. Two of the sampled specimens were adults, one female (CTIOC 13005) and one male (CTIOC13006), whereas three were nymphs (CTIOC13007 to CTIOC13009), and there were five eggs.

The molecular diagnoses for natural T. cruzi infections in two adult male specimens were positive. Given these results, the molecular content was sent to the genetic sequencing of $T$. cruzi strain, which was identified as discrete typing unit (DTU) type IV.

For the second T. williami colony, the feces from the three specimens were analyzed with a parasitological test and were infected by $T$. cruzi, whereas the other specimens were not infected. Two adult specimens, one female and one male, and two nymphs were deposited in "Collection Entomological Prof ${ }^{\circ}$ Dr. José Maria Soares Barata." in Faculty of Pharmaceutical Sciences UNESP - Araraquara - São Paulo Brazil.

\section{Discussion}

We reported a systematic collection of adults, nymphs, and eggs of $T$. williami inside human dwellings from Barra do Garças, Mato Grosso, Brazil, during two different years. In the second year, we found nymphs in the last developmental stage, suggesting early stages in the domestication of this sylvatic species. The domiciliation of wild triatomine species is a risk factor for reestablishing the vectorial transmission of ChD (SILVEIRA and DIAS, 2011; WALECKX et al. 2015). Surveillance for species, considering the domiciliation principle and the development of actions to interrupt this process, is paramount in preventing ChD. For Berenger and Pages (2007), the process of domestication seems irreversible.

Lunardi et al. (2017) discussed that morphological plasticity in the shape of $T$. williami is associated with blood source, but they did not test whether plasticity confers a fitness advantage to culminate in domiciliation by this species. However, in a previous study, Lunardi et al. (2015) recorded a high potential vector for nymphs of this species.

So far, T. williami has been considered a secondary $T$. cruzi vector because it maintains its wild condition and shows synanthropic potential, colonizing peridomiciles and, frequently, invading households. The synanthropy represents a secondary adaptation by sylvatic species in response to environmental changes. Such adaptability to human dwellings depends on triatomine plasticity (FORATTINI, 1980).

Given the increasing importance of secondary triatomine species and their frequency of occurrence within domiciliary environments, further eco-epidemiological studies should be stimulated to monitor changes in the behavior of these species. The behavioral characteristics of the different species of triatomines allow them to adapt to environmental changes, directly reflecting the population dynamics of these vectors. Thus, natural or anthropogenic environmental factors interfere with species density, dispersal, reproduction, and domiciliation (VAZQUEZ-PROKOPEC et al., 2006; GRIJALVA et al., 2014; CORASSA et al., 2016; VIANNA et al., 2017). 
The first T. williami specimen in Nova Xavantina, Mato Grosso, Brazil, was recorded by Travassos-Filho (1972). This specimen was collected inside the house of a worker and was infected by $T$. cruzi. Then, Arrais-Silva et al. (2011) and Andrade-Neto (2012), using molecular biology, found that the natural infection rate of this species by T. cruzi was $30 \%$ in Barra do Garças, Mato Grosso, Brazil. In our parasitological feces diagnosis, we observed an elevated infection rate of T. williami by T. cruzi in 2019 and 2020 , indicating the transmission risk of the parasite by this vector.

The finding of the TcIV DTU of T. cruzi in T. williami collected in the home is an unprecedented record for Mato Grosso, Brazil, and it is concerning. The distribution of DTU TcIV is more significant in Central and South America, with greater density in the Amazon region. In the Western Brazilian Amazon region, this is the leading cause of human infections, resulting from oral transmission outbreaks of the parasite in the region (MONTEIRO et al., 2012; TESTON et al., 2017; SANTANA et al., 2019). The origin of this DTU is derived as a wild cycle, but studies have already demonstrated its participation in domestic cycles (ZINGALES et al., 2012; BRENIÈRE et al., 2016), which are frequently correlated to acute ChD infections in humans. Studies analyzing triatomines from different biomes have not recorded this DTU for the Cerrado (BARROS et al., 2017). Therefore, this unprecedented record for Cerrado, the predominant biome in our study area. Izeta-Alberdi et al. (2016) found no correlation between TcIV and any vector species. Barros et al. (2017) found a predominance of this DTU for the Triatoma genus, corroborating the record of our study of this strain in T. williami. Regarding the potential reservoirs that participate in the transmission cycle of this parasite, the main mammals are carnivores, primates, and rodents (ZINGALES et al., 2012; IZETA-ALBERDI et al., 2016; BARROS et al., 2017).

The characteristics found for T. williami seem similar to those of T. infestans. According to Vinhaes et al. (2014), the protagonism of $T$. infestans can be justified due to its high degree of anthropophily, a large capacity to colonize human domiciles, and high rates of natural infection. The record of $T$. williami in the domiciliation process lights up an alert because there is a record of this species naturally infected by $T$. cruzi, with a high infection rate.

It is necessary to carry out immediate intervention measures to interrupt this process of domiciliation of T. williami in the urban area of Barra do Garças, Mato Grosso, Brazil. The approximation of vectors with human living spaces increases the risk of transmission of Chagas disease (CARVALHO and GOMES, 2014).

When we analyzed the records of the locations with triatomines in Barra do Garças over ten years, we identified a higher occurrence in households in the four neighborhoods bordering PESA. Thus, the presence of a green belt associated to the artificial light of these households might be supporting and promoting dispersion of the triatomines. Martins et al. (2019) reported that Barra do Garças, Mato Grosso, has a different ecological context, given its proximity to PESA. This state park may facilitate human contact with wild triatomines, which are potential vectors of ChD, especially in PESA neighborhoods. 
The occurrence of wild triatomine species sporadically invading human houses is a significant difficulty in vector surveillance programs (CARANHA et al., 2011). A study in a similar area, by Jácome-Pinilla et al. (2015), proved an actively dispersing area and triatomines highly attracted to artificial lights. Furthermore, the environmental parameters encountered during this study, particularly during the first hours after sunset, are favorable for the active dispersal of sylvatic triatomines. One immediate recommendation is that external artificial lights on walls must remain turned off during the first hours after sunset, the period when most sylvatic triatomines find favorable atmospheric and environmental conditions for dispersal.

Entomological surveillance for triatomines in Barra do Garças has been done mainly by the population, showing the importance of passive surveillance by residents to detect foci of the triatomines. Thus, we reinforce the importance of health education for $\mathrm{ChD}$ prevention. The passive surveillance improved risk management by the city health system, favoring timely intervention in the ChD transmission chain. This process corroborates that entomological surveillance has been supported by community referees responsible for the Triatomine Information Post Network (IPN), which has been established for a long time (SILVEIRA and DIAS, 2011). The knowledge of the population about triatomines and ChD is paramount to promoting collaboration in vector control and reducing vector transmission (VILLELA et al., 2009a, 2009b; COURA; JUNQUEIRA, 2012). Thus, the better the understanding, the greater the chance of intervening positively, preventing health problems and favoring healthier ways of life (AYRES, 2009).

Analysis of the triatomines collected in Barra do Garças in a historical ten-year series showed earlier demonstrates the increase in vector density in 2019. The results indicate periods with a peak incidence of triatomines in the third quarter of the year. Seasonality is also observed in Chagas vector populations and transmission. In combination with density-dependent regulation, these characteristics have led to the belief that insecticide control of these vectors can be improved if seasonally timed (GORLA, 1988; SCHOFIELD, 1991).

Thus, studies are needed to investigate the mammal fauna and triatomines in urban areas and adjoining neighborhoods of PESA to evaluate the dimensions and degrees of trypanosomal infection. These new studies will allow us to assess the infection risks of humans around the park, considering the presence of the etiological agent of ChD.

The finding of $T$. williami colonies inside homes and the high rate of natural infection for this species reinforces the need to study reservoirs and their role in maintaining and or dispersing $T$. cruzi. The main determinants for establishing human infection by $T$. cruzi involve the adaptation of triatomines to the domicile and peridomicile and the T. cruzi circulation between wild and domestic animals in these environments (COURA, 2007).

However, understanding variation in vector infection prevalence alone is not enough to understand the risk to humans from the vector-related transmission. Several factors affect the relationship between vectors and the prevalence of human infection (BROWNE et al., 2016). The maintenance of sustainable surveillance activities is possible only if all transmission network components are identified (NOIREAU et al., 2009). These measures are essential for the sustainability of the control of ChD, since the re- 
infestation of homes by native triatomines occurs continuously, and as there are wild foci of vector species of T. cruzi, there is a risk of infection of the reservoirs (PRIOTTO, 2012).

The detection of possible triatomine domiciliation in the urban area of Barra do Garças, Mato Grosso, Brazil, demonstrates the importance of entomological surveillance and underscores the importance of strengthening prevention programs and controlling ChD infections. Our results reinforce the importance of and need for entomological surveillance in routine home visits by health field agents. Therefore, maintaining and systematizing chemical control measures and following the Brazilian Ministry of Health protocol and environmental management in households to reduce the risk of $\mathrm{ChD}$ infection in endemic areas of the state of Mato Grosso, Brazil, is of utmost importance.

\section{Conclusion}

As far as we know, this study is the first to confirm the domiciliation of T. williami in urban areas of Barra do Garças, Mato Grosso, Brazil. This record occurred after sporadic invasions by this species in domiciles near an environmental conservation unit. This park is composed of native vegetation and wild animals, which are possible reservoirs for $T$. cruzi. These conditions reinforce the importance of entomological surveillance for the sanitary control of triatomines. Further studies are need to understand better the ecology of these species for their prevention and control mechanisms, since they have a high natural infection rate by $T$. cruzi.

\section{Declarations}

\section{Ethics approval and consent to participate}

Not applicable

\section{Consent for publication}

Not applicable

\section{Competing Interests}

The authors declare that they have no competing interests.

\section{Funding}

Foundation Project: Supported by Fundação de Amparo à Pesquisa do Estado de Mato Grosso ( $\mathrm{N}^{\circ}$. 276237/18-PPPSUS) and Conselho Nacional de Desenvolvimento Científico e Tecnológico (CNPq).

\section{Authors' contributions}

MFM, JCS, and JO contributed to the preparation of the manuscript; CG was responsible for identifying the studied specimens and text review; SCM organized, prepared, and analyzed data; and LKSS realized 
textual revision.

\section{Acknowledgments}

To Secretaria de Estado de Saúde de Barra do Garças, Mato Grosso, Brazil, for supporting surveillance actions in health.

To ACEs da Secretaria Municipal de Saúde de Barra do Garças, Mato Grosso, Brazil, responsible for Chagas disease surveillance, and Ana Gomes da Silva for carrying out the parasitological diagnosis of feces.

To residents for passive surveillance of triatomines.

JO would like to thank the São Paulo State Research Support Foundation (FAPESP, Brazil).

JCS would like to thank Coordination for the Improvement of Higher Education Personnel (CAPES, Brazil) for the M.Sc. fellowship.

\section{References}

1. Abad-Franch F, Diotaiuti L, Gurgel-Gonçalves R, Gürtler RE. Certifying the interruption of Chagas disease transmission by native vectors: cui bono? Mem. Inst. Oswaldo Cruz. 2013; 108(2): 251-54. https://doi.org/10.1590/0074-0276108022013022

2. Alevi KCC, Oliveira J, Garcia ACC, Cristal DC, Delgado LMG, de Freitas Bittinelli I, et al.Triatoma rosai sp. nov. (Hemiptera, Triatominae): A New Species of Argentinian Chagas Disease Vector Described Based on Integrative Taxonomy.Insects 2020; 11(12): 830. https://doi.org/10.3390/insects 11120830

3. Almeida CE, Folly-Ramos E, Peterson AT, Lima-Neiva V, Gumiel M, Duarte R, Lima MM, Locks M, Beltrão M and Costa J. Could the bug Tri a to $m$ a s $h$ e r l o ck / be vectoring Chagas disease in small mining communities in Bahia, Brazil? Medical and Veterinary Entomology 2009; 23: 410-417. https://doi.org/10.1111/j.1365-2915.2009.00822.x

4. Almeida CE, Vinhaes MC, de Almeida JR, Silveira AC, Costa J. Monitoring the Domiciliary and Peridomiciliary Invasion Process of Triatoma rubrovaria in the State of Rio Grande do Sul, Brazil. Mem. Inst. Oswaldo Cruz 2000; 95(6): 761-768. https://doi.org/10.1590/S007402762000000600003

5. Almeida PS, Ceretti Júnior W, Obara MT, Santos HR, Barata JMS, Faccenda O. Levantamento da fauna de Triatominae (Hemiptera: Reduviidae) em ambiente domiciliar e infecção natural por Trypanosomatidae no Estado de Mato Grosso do Sul. Rev. Soc. Bras. Med. Trop. 2008; 41(4): 374380. https://doi.org/10.1590/S0037-86822008000400010

6. Andrade-Neto OA, de Arruda MCC, Kerkho J, Lunardi RR, Arrais-Silva WW. Risk of domiciliation of Triatoma williami Galvão, Souza e Lima, 1965 in a municipality of Brazilian Legal Amazon region. Asian Pac Trop Med Press 2012; 2(1): 265-267. https://doi.org/10.1016/S2222-1808(12)6. 
7. Añez N, Crisante G, Agustina R, Diaz N, Diaz S, Lizano E, Superlano Y, Aldana E. Domiciliación de Triatoma nigromaculata de la región montana del sur de Mérida, Venezuela. Boletín de Malariología Y Salud Ambiental Vol. XLV, No 1, Enero-Julio, 2005.

8. Arrais-Silva WW, Rodrigues RSV, de Moraes LN, Venere PC, Lunardi RR, Souza IL, Souto PCS. First report of occurrence of Triatoma williami Galvão, Souza e Lima, 1965 naturally infected with Trypanosoma cruzi Chagas, 1909 in the State of Mato Grosso, Brazil, 2011. https://doi.org/10.1016/S2222-1808(11)60040-6

9. Assis GLM, Azeredo BVM, Carbajal de la Fuente AL, Diotaiuti L and Marta de Lana. Domiciliation of Triatoma pseudomaculata (Corrêa e Espínola 1964) in the Jequitinhonha Valley, State of Minas Gerais. Rev. Soc. Bras. Med. Trop. 2007; 40(4): 391-396. https://doi.org/10.1590/S003786822007000400003

10. Ayres JRCM. Prevenção de Agravos, Promoção da Saúde e Redução da Vulnerabilidade. In: Martins MA, Carrilho FJ, Alves VA, Castilho CG, Wen CL. Clínica Médica. Barueri: Manole 2009. p. 437-455. http://observatorio.fm.usp.br/handle/OPI/15187

11. Barros JHS, Xavier SCC, Bilac D, Lima VS, Dario MA, Jansen AM. Identification of novel mammalian hosts and Brazilian biome geographic distribution of Trypanosoma cruzi Tclll and TcIV. Acta Trop. 2017; 172: 173-9. https://doi.org/10.1016/j.actatropica.2017.05.003

12. Berenger JM, Pages F. Les Triatominae: une domestication qui se généralise. Med Trop 2007; 67: 217-222.

13. Brandão HR, Fonseca EOL, Santos RF, Ribeiro-Júnior G, Santos CGS, Cova BO, Will RMMM, Reis MG. Descrição de focos residuais de Triatoma infestans (Klug, 1834) no município de Novo Horizonte, Bahia. Rev Baiana de Saúde Pública 2015; 39(1): 91-104. https://doi:10.5327/Z01000233-201539S100009

14. Brenière SF, Waleckx E, Barnabé C. Over Six Thousand Trypanosoma cruzi Strains Classified into Discrete Typing Units (DTUs): Attempt at an Inventory. PLoS Neglected Tropical Diseases 2016; 10(8): e0004792.https://doi.org/10.1371/journal.pntd.0004792

15. Brígido RTS, Tavares PCB, Santos MA, Santos JG, Souza MA, Goulart IMB, Silva CV. Trypanosoma cruzi modulates gene expression of plasma membrane repair-related proteins.Acta Tropica 2017; 174: 153-157. https://doi.org/10.1016/j.actatropica.2016.06.008

16. Browne AJ, Guerra CA, Alves RV, da Costa VM, Wilson AL, Pigott DM, Hay SI, Lindsay SW, Golding N, Moyes CL. The contemporary distribution of Trypanosoma cruzi infection in humans, alternative hosts and vectors. SCIENTIFIC DATA | 4:170050 https://doi:10.1038/sdata.2017.50

17. Caranha L, Gurgel-Gonçalves R, Ramalho RD, Galvão C. New records and geographic distribution map of Triatoma petrocchiae Pinto and Barreto, 1925 Hemiptera: Reduviidae: Triatominae). Check List 2011; 7(4): 508-509. http://dx.doi.org/10.15560/7.4.508

18. Carbajal de la Fuente AL, Dias-Lima A, Lopes CM, Emperaire L, Walter A, Ferreira A, Sherlock I, Noireau F. Behavioral plasticity of triatominae related to habitat selection in northeast Brazil, J. Med. Entomol. 2008; 45: 14-19. https://doi.org/10.1093/jmedent/45.1.14 
19. Carvalho DM, Gomes WS. Distribuição de triatomíneos hemíptera, Reduviidae, Triatominae nos municípios da mesorregião sul do estado do Ceará, no período de 2010 a 2012. Cadernos ESP 2014; 8(2): $30-37$.

20. CEVS/Rio Grande do Sul. Boletim epidemiológico. v. 11 | n. 3 | 2009.

21. Cosentino RO, Aguëro F. A Simple Strain Typing Assay for Trypanosoma cruzi. Discrimination of Major Evolutionary Lineages from a Single Amplification Product. PLoS Neglected Tropical Diseases 2012;6(7):1777. Corassa RB, Aceijas C, Alves PAB, Garelick H. Evolution of Chagas' disease in Brazil. Epidemiological perspective and challenges for the future: a critical review. Perspect Public Health [Internet]. 2016. Available from: http://journals.sagepub.com/doi/pdf/10.1177/1757913916671160

22. Coura JR. Chagas disease: what is known and what is needed-A background article. Mem. Inst. Oswaldo Cruz 2007; 102(I): 113-122. https://doi.org/10.1590/S0074-02762007000900018

23. Coura JR, Junqueira ACV. Risks of endemicity, morbidity and perspectives regarding the control of Chagas disease in the Amazon Region. Mem. Inst. Oswaldo Cruz 2012; 107(2):145-154. https://doi.org/10.1590/S0074-02762012000200001

24. Dale C, Justi AS, Galvão C. Belminus santosmalletae (Hemiptera: Heteroptera: Reduviidae): New Species from Panama, with an Updated Key for Belminus Stål, 1859 Species. Insects 2021; 12:686. https://doi.org/10.3390/insects12080686

25. Depickère S, Buitrago R, Siñani E, Baune M, Monje M, et al. Susceptibility and resistance to deltamethrin of wild and domestic populations of Triatoma infestans (Reduviidae: Triatominae) in Bolivia: new discoveries. Mem. Inst. Oswaldo Cruz 2012; 107(8): 1042-1047. https://doi.org/10.1590/S0074-02762012000800013

26. Forattini OP. Biogeografia, origem e distribuição da domiciliação de triatomíneos no Brasil. Rev. Saúde Públ. 1980; 14: 265-299. http://dx.doi.org/10.1590/S0034-89102006000700004

27. Izeta-Alberdi A, Ibarra-Cerdeña CN, Moo-Llanes DA, Ramsey JM. Geographical, landscape and host associations of Trypanosoma cruzi DTUs and lineages. Parasit. Vectors. 2016; 9: 631. https://doi:10.1186/s13071-016-1918-2

28. Gorla DE. Seasonal effects on control strategies of Chagas' disease vectors. Rev Argent Microbiol 1988; 20: 71-80.

29. Köppen W (1948) Climatologia: comun estudio de los climas de la tierra. Fondo de Cultura Economica, México, 478 pp.

30. Lent H, Wygodzinsky P. Revision of the Triatominae (Hemiptera, Reduviidae), and their significance as vectors of Chagas Disease. Bul Amer Mus Nat Hist 1979; 63: 520-529. http://hdl.handle.net/2246/1282

31. Lunardi RR, Benítez H A, Câmara TP, Gomes PL, Arrais-Silva WW. Head variation in response to diet of Triatoma williami (Galvão, Souza e Lima, 1965). Zoologisher Aizenger 2017; 266:187193.

32. Lunardi RR, Gomes LP, Câmara TP, Arrais-Silva WW. Life cycle and vectorial competence of Triatoma williami (Galvão, Souza e Lima, 1965) under the influence of different blood meal sources. Acta Trop. 2015; 149: 220-226. https://doi.org/10.1016/j.actatropica.2015.05.023 
33. Galvão C. Taxonomia dos Vetores da Doença de Chagas da Forma à Molécula, quase três séculos de história. In: Atualidades em Medicina Tropical no Brasil: Vetores ( $1^{\circ} \mathrm{ed}$.) (Oliveira J, Alevi KC, Camargo, Meneguetti LMA, D.U.O., ed.) Stricto Sensu Editora 2020; pp. 9-37.

34. Galvão C, org. Vetores da doença de chagas no Brasil [online]. Curitiba: Sociedade Brasileira de Zoologia, 2014, 289 p. Zoologia: guias e manuais de identificação series. ISBN 978-85-98203-09-6. Available from SciELO Books http://books.scielo.org

35. Galvão C, Rocha, DS, Juberg J, Carcavallo RU. Ampliação da distribuição geográfica de Triatoma deaneorum Galvão, Souza \& Lima, 1967, nova denominação para Triatoma deanei (Hemiptera, Reduviidae). Rev. Soc. Bras. Med. Trop. 2001; 34: 587-589. https://doi.org/10.1590/S0037-86822001000600015

36. Grijalva MJ, Tera'n D, Dangles O. Dynamics of Sylvatic Chagas Disease Vectors in Coastal Ecuador Is Driven by Changes in Land Cover. PLOS Negl Trop Dis 2014; 8(6): e2960. https://doi:10.1371/journal.pntd.0002960

37. Instituto Brasileiro de Geografia e Estatística. http://www.ibge.gov.br/cidadesat/topwindow.htm?1. Acessed 09 Mar 2017.

38. Jácome-Pinilla D, Hincapie-Peñaloza E, Ortiz MI, Ramírez JD, Guhl F, Molina J. Risks associated with dispersive nocturnal flights of sylvatic Triatominae to artificial lights in a model house in the northeastern plains of Colombia. Parasit. Vectors. 2015 ; 8: 600. https://doi:10.1186/s13071-015$1209-3$

39. Luitgards-Moura JF, Vargas AB, Almeida CA, Magno-Esperança G, Agapito-Souza R, Folly-Ramos E, Costa J, Tsouris P, Rosa-Freitas MG. A Triatoma maculata (Hemiptera, Reduviidae, Triatominae) populations from Roraima, Amazon region, Brazil, hassome bionomic characteristic of a potential Chagas disease vector. Rev Inst Med Trop 2005; 47: 131-137. https://doi.org/10.1590/S003646652005000300003

40. Matias A, Riva de La J, Martinez E, Torrez M, Dujardin JP. Domiciliation process of Rhodnius stali (Hemiptera: Reduviidae) in Alto Beni, La Paz, Bolivia. Tropical Medicine and International Health 2003; 8(3): 264-268. https://doi.org/10.1046/j.1365-3156.2003.01021.x

41. Martins MF, Moraes SC, Obara MT, Galvão C. Panstrongylus diasi Pinto \& Lent, 1946 (Hemiptera, Reduviidae, Triatominae): first record in Mato Grosso, Brazil. Check List 2019; 15(2): 259-264. https://doi.org/10.15560/15.2.259

42. Ministério do Meio Ambiente (MMA) Secretaria de biodiversidade e florestas. Avaliação e identificação de áreas e ações prioritárias para conservação, utilização sustentável e repartição dos benefícios da biodiversidade nos biomas brasileiros. Brasília 2002; 404 pp.

43. Ministério da Saúde. Secretaria de Vigilância em Saúde. Boletim epidemiológica 2015; 46: 21.

44. Monteiro FA, Weirauch C, Felix M, Lazoski C, Abad-Franch F. Evolution, Systematics, and Biogeography of the Triatominae, Vectors of Chagas Disease. Adv Parasitol. 2018; 99: 265-344. https://doi:10.1016/bs.apar.2017.12.002 
45. Monteiro WM, Magalhães LKC, de Sá ARN, Gomes ML, Toledo MJdO, et al. Trypanosoma cruzi IV Causing Outbreaks of Acute Chagas Disease and Infections by Different Haplotypes in the Western Brazilian Amazonia. PLOS ONE 2012; 7(7): e41284. https://doi.org/10.1371/journal.pone.0041284

46. Noireau F, Diosque P, Jansen AM. Trypanosoma cruzi: adaptation to its vectors and its hosts. Vet. Res. 2009. https://doi:10.1051/vetres/2009009

47. Noireau F, Dujardin JP. Biology of Triatominae. In J Telleria, M Tibayrenc (eds.), American trypanosomiasis: Chagas disease one hundred years of research, Elsevier, Burlington; 2010.

48. Oliveira J, Alevi KCC. Taxonomic status of Panstrongy/us herreri Wygodzinsky, 1948 and the number of Chagas disease vectors. Rev. Soc. Bras. Med. Trop. 2017; 50(3): 434-435. https://doi.org/10.1590/0037-8682-0125-2017

49. Priotto MM. Aspectos gerais da vigilância entomológica da doença de Chagas na Região Sul do Rio Grande do Sul, Brasil Fornel R. Estudo da variação morfológica craniana entre quatro blocos populacionais de Ctenomys lami (Rodentia, Ctenomyidae) através de morfometria geométrica [Dissertação]. Pelotas: Instituto de Biologia. Departamento de Microbiologia e Parasitologia; 2012.

50. Reyes-Lugo M, Rodríguez-Acosta A. Domiciliation of selvatic Chagas disease vector Panstrongylus geniculatus Latreille 1811 (Triatominae: Reduviidae) in Venezuela. Trans Roy Soc Trop Med Hyg 2000; 94: 508. https://doi.org/10.1016/s0035-9203(00)90068-3

51. Reyes-Lugo M, Reyes-Contreras M, Salvi I, Gelves W, Avilán A, Llavaneras D, Navarrete LF, Cordero G, Sánchez EE, Rodríguez-Acosta A. The association of Triatoma maculata (Ericsson 1848) with the gecko Thecadactylus rapicauda (Houttuyn 1782) (Reptilia: Squamata: Gekkonidae): a strategy of domiciliation of the Chagas disease peridomestic vector in Venezuela? Asian Pac J Trop Biomed 2011; 1(4): 279-284. https://doi:10.1016/S2221-1691(11)60043-9

52. Ricardo-Silva A, Gonçalves TCM, Luitgards-Moura JF, Lopes CM, da Silva SP, Bastos AQ, et. al. Triatoma maculata colonises urban domicilies in Boa Vista, Roraima, Brazil. Mem. Inst. Oswaldo Cruz 2016; 111(11): 703-706.

53. Santana RAG, Guerra MGVB, Couceiro K, Ortiz JV, Oliveira M, et al. Oral Transmission of Trypanosoma cruzi, Brazilian Amazon. Emerging Infectious Diseases 2019; 25(1). www.cdc.gov/eid

54. Santos MS, Sousa DM, Santos JP, Vieira JFPN, Gonçalves TCM, et al. Entomological survey in the state of Piauí, Northeastern Brazil, reveals intradomiciliary colonization of Triatoma brasiliensis macromelasoma. Rev. Inst. Med. trop. S. Paulo 2017; 59. https://doi:org/10.1590/S16789946201759027

55. Schofield CJ. Vector population responses to control interventions. Ann Soc Belg Med Trop 1991; 71(1): 201-17.

56. Sievers F, Higgins DG. Clustal omega. Current protocols in bioinformatics, [S.I.], 2014; 48(1): 3-13. https://doi.org/10.1002/0471250953.bi0313s48

57. Silva JMC, Bates JM. Biogeographic Patterns and Conservation in the South American Cerrado: A Tropical Savanna Hotspot. Bio Science 2002; 52: 225-234. https://doi.org/10.1641/00063568(2002)052[0225:BPACIT]2.0.CO;2 
58. Silva MBA, Menezes KR, Siqueira AM, Balbino VQ, Lorosa ES, Farias MCG, Freitas MTS, Silva A, Portela VMC, Jurberg J. Importância da distribuição geográfica dos vetores da doença de chagas em Pernambuco, Brasil, em 2012. Rev Patol Trop, 2015; 44(2): 195-206. https://doi.org/10.5216/rpt.v44i2.36650

59. Silva RA, Gonçalves TCM, Luitgards-Moura JF, Lopes CM, Silva SP, et al. Triatoma maculata colonises urban domicilies in Boa Vista, Roraima, Brazil. Mem. Inst. Oswaldo Cruz 2016; 111(11): 703-706. https://doi.org/10.1590/0074-02760160026

60. Silva RA, Virgino F, Estevão VAO, Martins ML, Duarte NA, et al. First report of colonization by Panstrongylus megistus (Burmeister, 1835) (Hemiptera, Reduviidae, Triatominae) in the Metropolitan Region of São Paulo, Brazil. Brazilian Journal of Biology [online]. 2021; 81(1). https://doi.org/10.1590/1519-6984.225562

61. Silveira AC. Situação do controle da transmissão vetorial da doença de Chagas nas Américas. Cad. Saúde Públ. 2000; 16 Supl Il: 35-42. https://doi.org/10.1590/S0102-311X2000000800004

62. Silveira AC and Dias JCP. $O$ controle da transmissão vetorial. In História da doença de Chagas no Brazil 2011; 44 Supl II:52-63. https://doi.org/10.1590/S0037-86822011000800009

63. Soto-Vivas A, Bazarte H, Fernandéz DM. Primer registro de Eratyrus mucronatus Stål, 1959 (Hemiptera: Reduviidae) en el ambiente domiciliário em Venezuela (sic). Entomotropica 2001; 16: 215-217. http://hdl.handle.net/1807/5758

64. Souza ES, Von Atzingen NCB, Furtado MB, Oliveira J, Nascimento JD, et al. Description of Rhodnius marabaensis sp. n. (Hemiptera, Reduviidae, Triatominae) from Pará State, Brazil. Zookeys 2016; 621: 45-62. https://doi.org/10.3897/zookeys.621.9662

65. Teston APM, Abreu AP, Abegg CB, Gomes LM, Toledo MJO. Outcome of oral transmission in mice inoculated with Trypanosoma cruzi IV of the Western Brazilian Amazon. Acta Trop. 2017; 166: 212217. https://doi.org/10.1016/j.actatropica.2016.11.019

66. Teves SC, Gonçalves TCM, de Freitas SPC, Lopes CM, Carbajal-de-la-Fuente AL Santos-Mallet JR. External female genitalia of Triatoma jatai, Triatoma costalimai and Triatoma williami (Hemiptera: Reduviidae: Triatominae). Parasit. Vectors. 2020; 13(538). https://doi.org/10.1186/s13071-02004418-2

67. Travassos-Filho LP. Triatoma williami Galvão, Souza e Lima, 1965, capturado em Mato Grosso, BR Novo vector da doença de Chagas. Mem. Inst. Butantã 1972; 36: 263-266.

68. Valente VC. Potential for domestication of Panstrongy/us geniculatus (Latreille, 1811) (Liemiptera, Reduviidae, Triatominae) in the municipality of Muaná, Marajó Island, State of Pará, Brazil (sic). Mem. Inst. Oswaldo Cruz 1999; 94: 399-400. https://doi.org/10.1590/S0074-02761999000700078

69. Vazquez-Prokopec GM, Ceballos LA, Marcet PL, Cecere MC, Cardinal MV, Kitron U et. al. Seasonal variations in active dispersal of natural populations of Triatoma infestans in rural north-western Argentina. Medical and Veterinary Entomology 2006; 20: 273-279.

https://dx.doi.org/10.1111\%2Fj.1365-2915.2006.00637.x 
70. Vianna N, Souza E, Guimarães RJP, Souza CR, Gorla DE, Diotauiti L. Chagas disease ecoepidemiology and environmental chages in northern Minas Gerais State, Brazil. Mem. Inst. Oswaldo Cruz 2017; 112(11): 760-768. https://doi.org/10.1590/0074-02760170061

71. Villela MM, Souza JMBS, Melo VP, Dias JCP. Avaliação do Programa de Controle da Doença de Chagas em relação à presença de Panstrongylus. Cad. Saúde Públ. 2009a; 25(4): 907-917. https://doi:10.1590/S0102-311X2009000400022

72. Villela MM, Pimenta DN, Lamounier PA, Dias JCP. Avaliação de conhecimentos e práticas que adultos e crianças têm acerca da doença de Chagas e seus vetores em região endêmica de Minas Gerais, Brasil. Cad. Saúde Públ. 2009b; 25(8): 1701-1710. https://doi.org/10.1590/S0102$311 \times 2009000800006$

73. Vinhaes MC, Oliveira SV, Reis PO, Sousa ACL, Silva RA, Obara MT, et al. Assessing the vulnerability of Brazilian municipalities to the vectorial transmission of Trypanosoma cruzi using multi-criteria decision analysis. Acta Trop. 2014; 137: 105-10. https://doi.org/10.1016/j.actatropica.2014.05.007

74. Waleckx E, Gourbière S, Dumonteil E. Intrusive versus domiciliated triatomines and the challenge of adapting vector control practices against Chagas disease. Mem. Inst. Oswaldo Cruz 2015; 110(3): 324-338. https://doi.org/10.1590/0074-02760140409

75. Wolff M, Castillo D. Domiciliation Trend of Panstrongylus rufotuberculatus in Colombia. Mem. Inst. Oswaldo Cruz 2002; 97(3): 297-300. https://doi.org/10.1590/S0074-02762002000300003

76. World Health Organization, Control of Chagas disease, Techn. Rep. Ser. No. 905, Geneva; 2002.

77. Zhao Y, Galvão C, Cai W. Rhodnius micki, a new species of Triatominae (Hemiptera, Reduviidae) from Bolivia. ZooK. 2021; 1012: 71-93. https://doi.org/10.3897/zookeys.1012.54779

78. Zingales B, Miles MA, Campbell DA, Tibayrenc M, Macedo AM, Teixeira MM, et al. The revised Trypanosoma cruzi subspecific nomenclature: rationale, epidemiological relevance and research applications. Infect Genet Evol 2012; 12: 240-53. https://doi.org/10.1016/j.meegid.2011.12.009

\section{Figures}




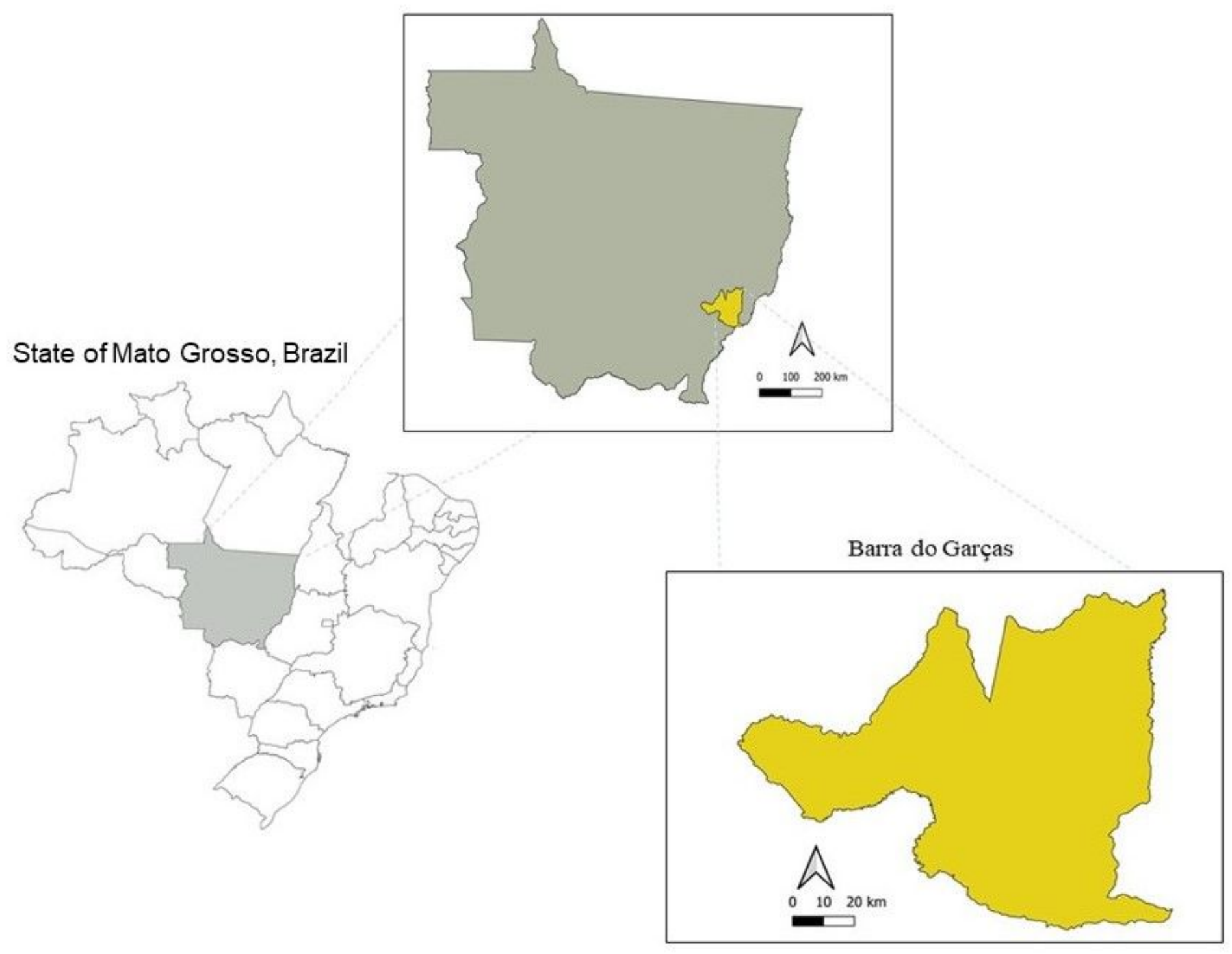

\section{Figure 1}

Municipality of Barra do Garças, Mato Grosso, Brazil. Adapted from the Brazilian Institute of Geography and Statistics (Instituto Brasileiro de Geografia e Estatística - IBGE). 


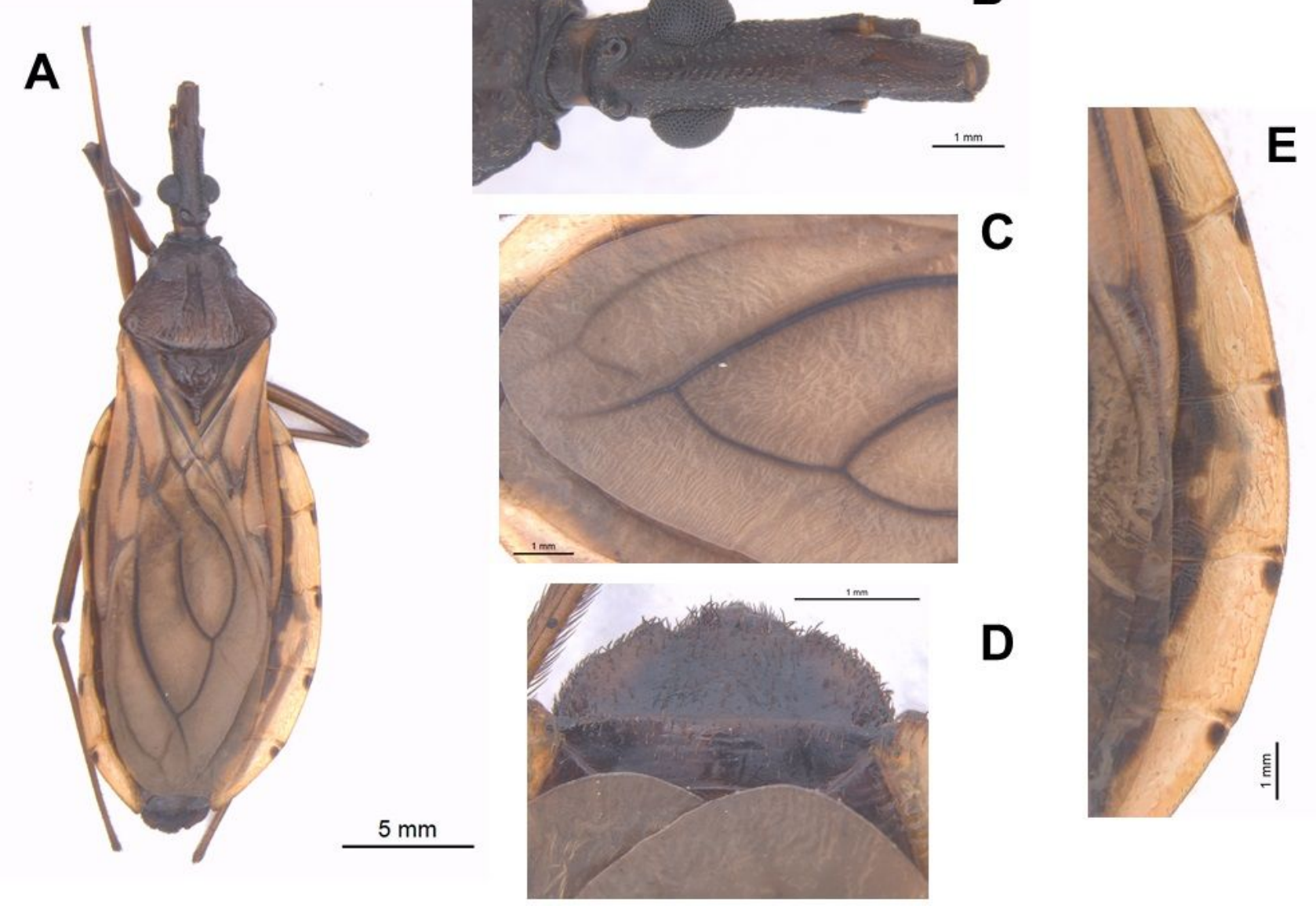

Figure 2

A. Adult female of Triatoma williami; B. Head detail in the dorsal view of the specimens; C. wing venation pattern detail of the specimens; D. External female genitalia by dorsal view; E. General appearance of the connexivum chromatic pattern. 


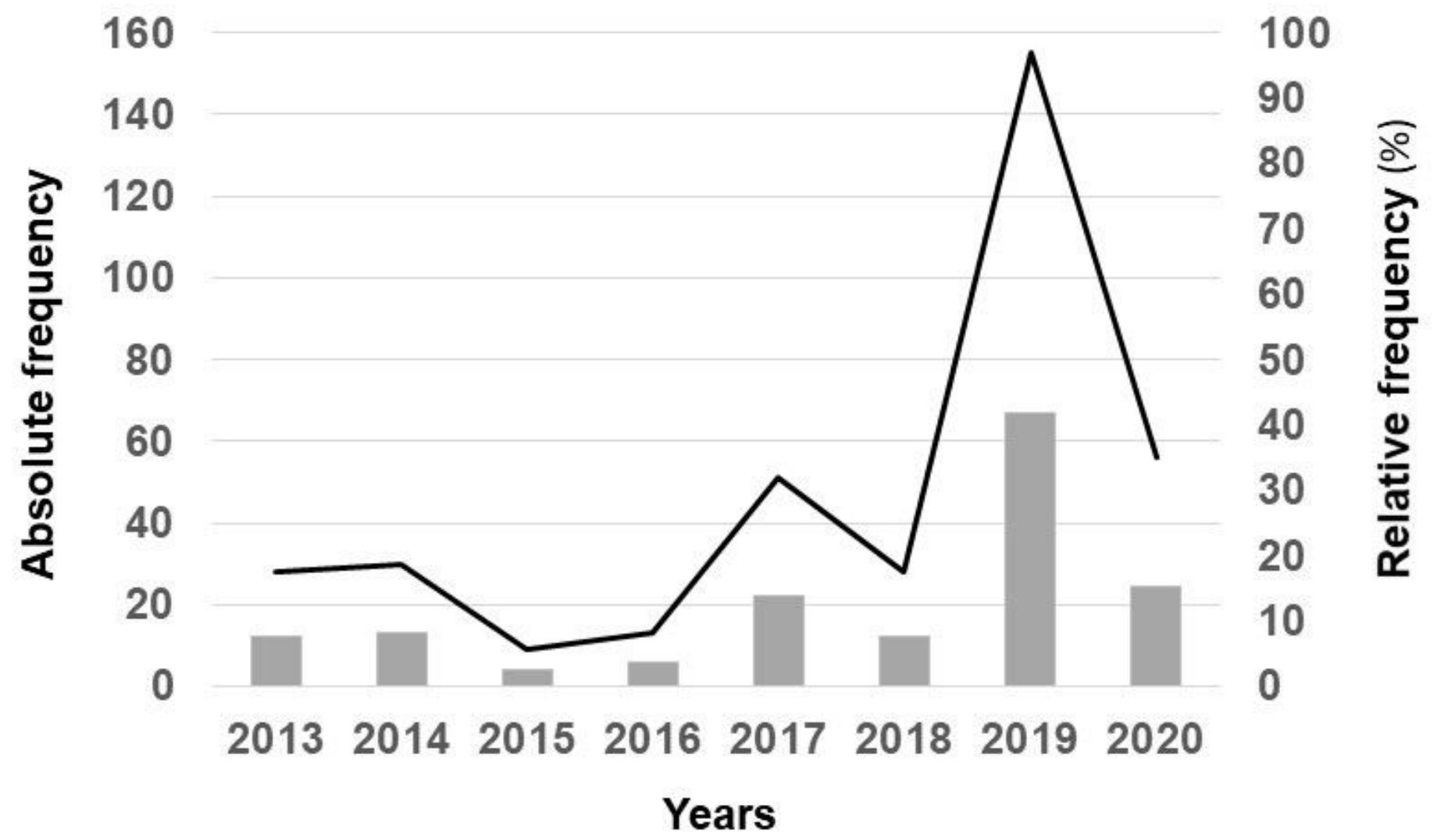

Figure 3

The absolute and relative frequencies of triatomines collected in Barra do Garças, Mato Grosso, Brazil, from 2013 to 2020. 


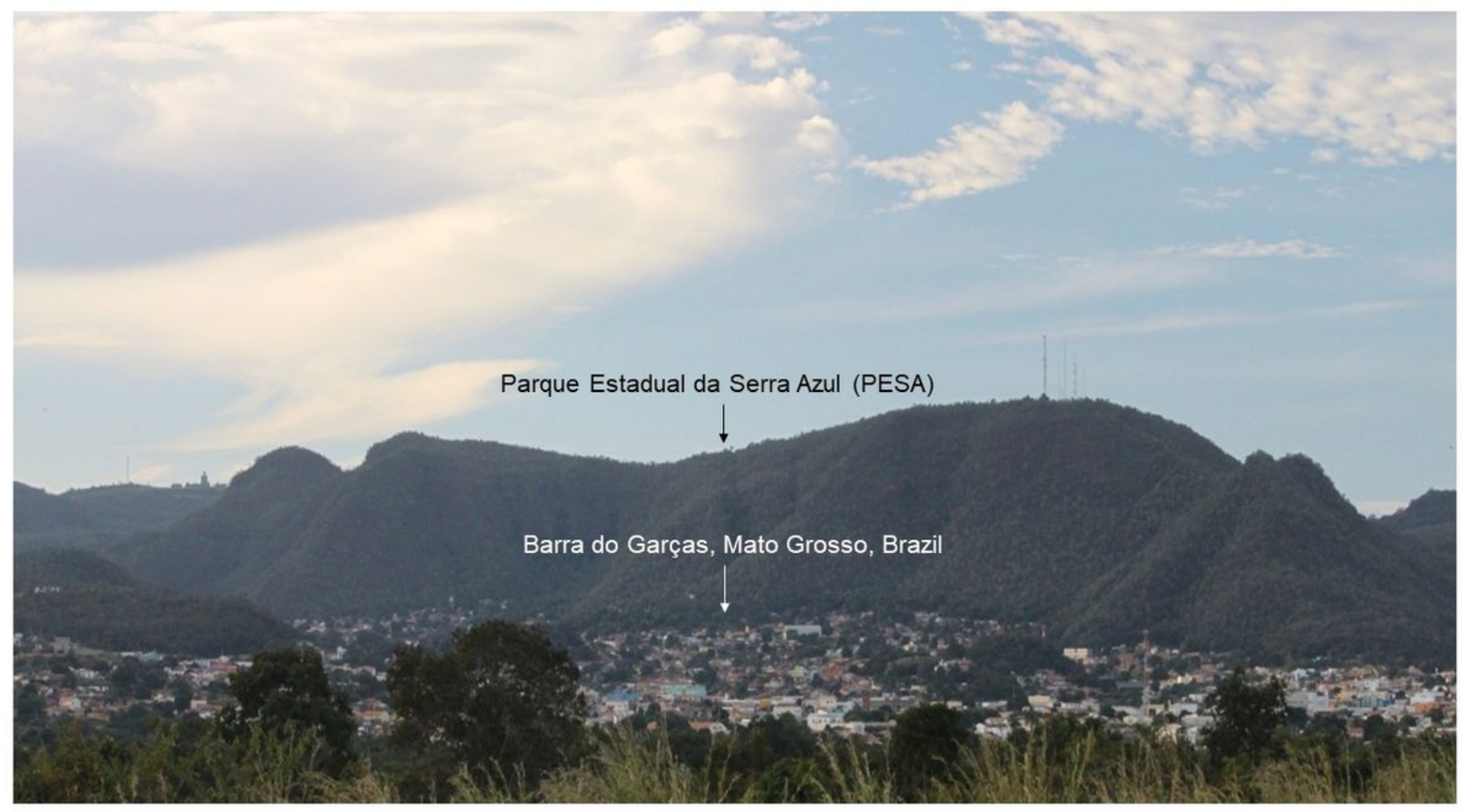

Figure 4

Panoramic view of the Barra do Garças municipality and the Parque estadual da Serra Azul (PESA), Mato Grosso, Brazil. 


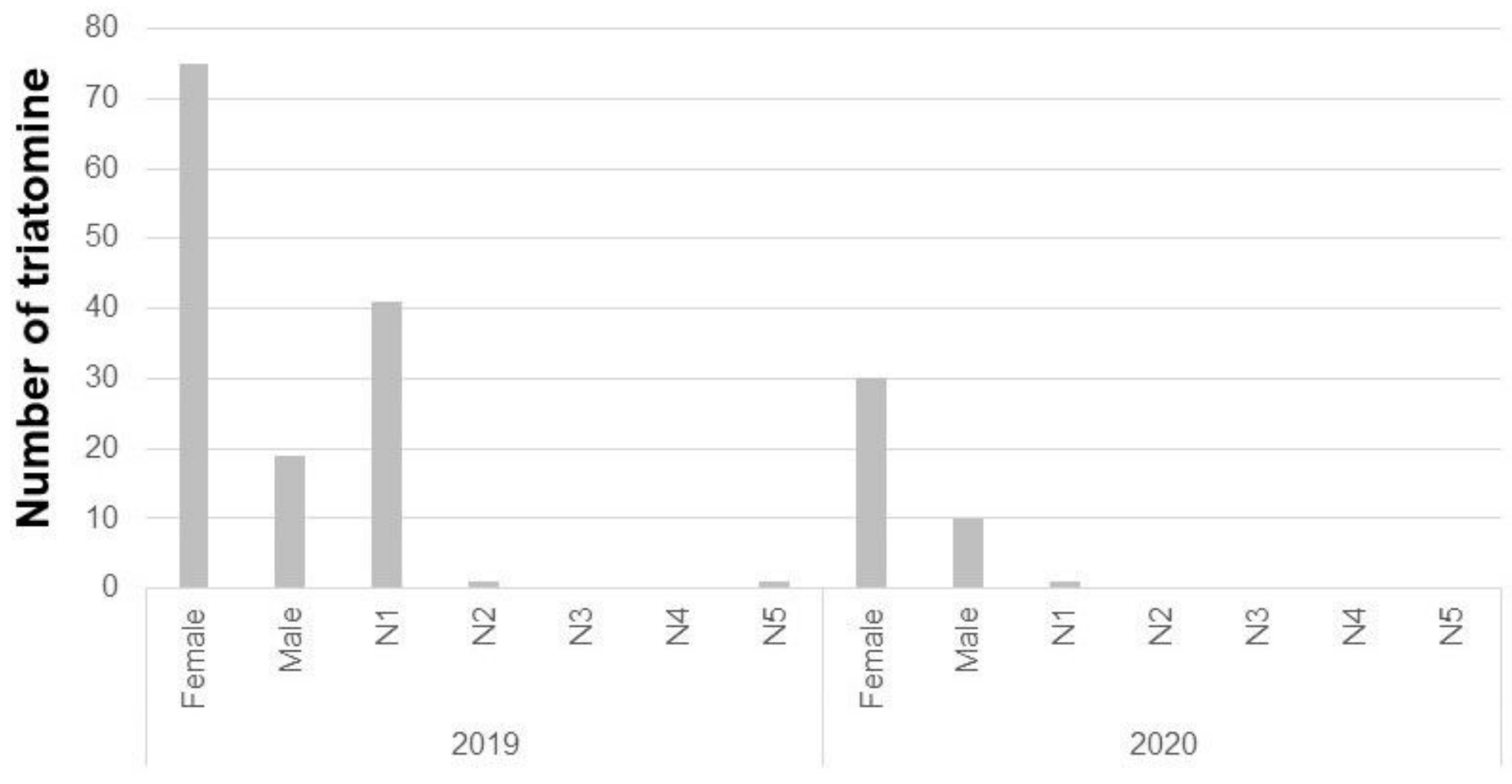

\section{Development stages}

\section{Figure 5}

The density of adults and nymphs of Triatoma williami sampled in Barra do Garças, Mato Grosso State, Brazil from 2019 to 2020, according to sex and life developmental stage. N1: first stage nymph; N2: second stage nymph; N3: third stage nymph; N4: fourth stage nymph; N5: fifth stage nymph. 


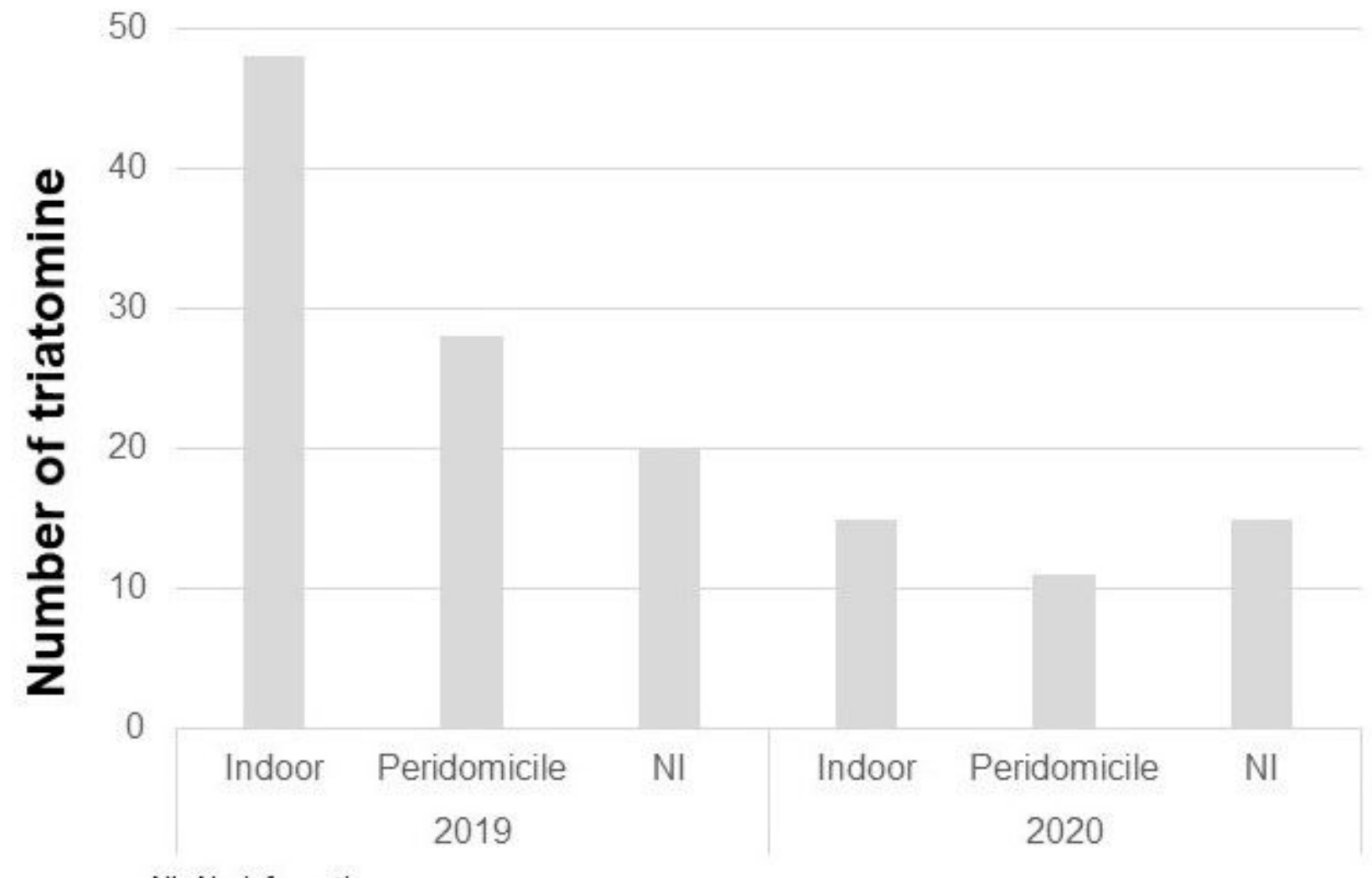

NI- No information

\section{Environment}

\section{Figure 6}

The density of Triatoma williami collected from 2019 to 2020 in Barra do Garças, Mato Grosso, Brazil, from 2019 to 2020 in each environment. Source: Data recorded on the monthly sheet related to the ChD Control Program, State Health Secretariat of Mato Grosso, Brazil. 


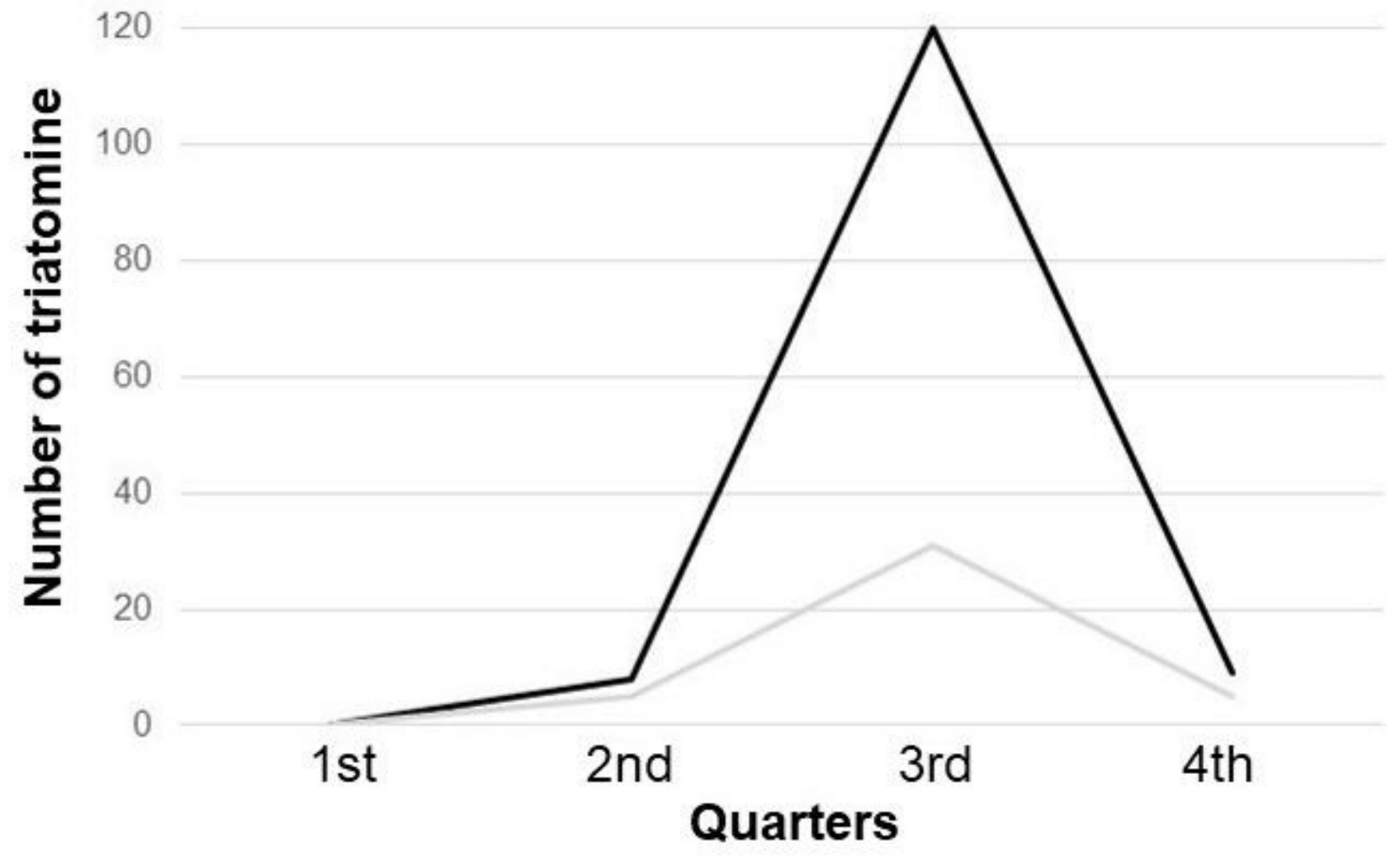

$-2019-2020$

Figure 7

The monthly density of Triatoma williami collected (between 2019 and 2020) in Barra do Garças, Mato Grosso, Brazil. 


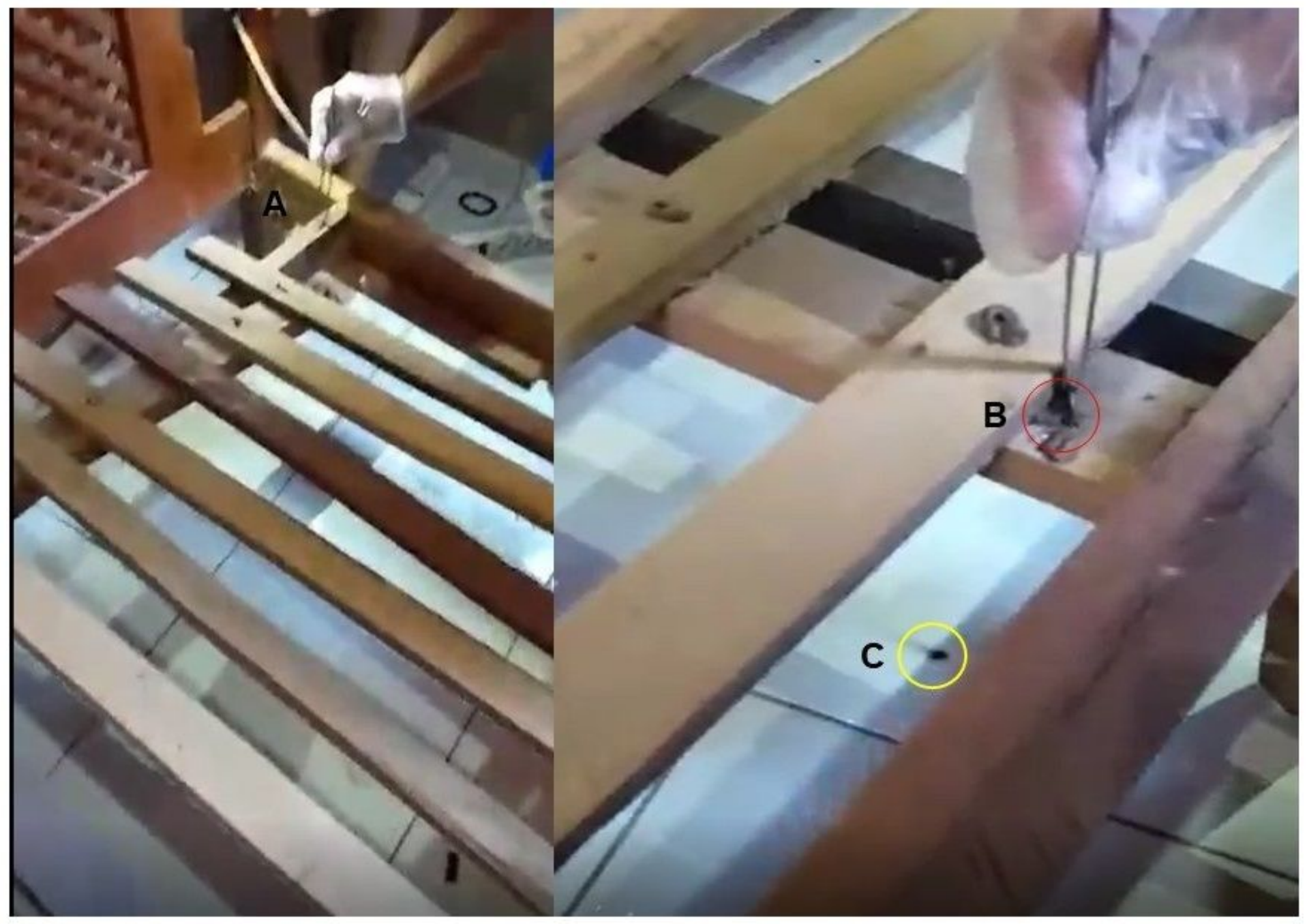

\section{Figure 8}

A. The field agents performed the entomological survey in the cracks of a bed of the resident. B. One adult of Triatoma williami collected in bed (red circle) in a residence from the Barra do Garças municipality, Mato Grosso, Brazil, in 2020. C. Traces of feces on the floor under the bed (yellow circle).

A

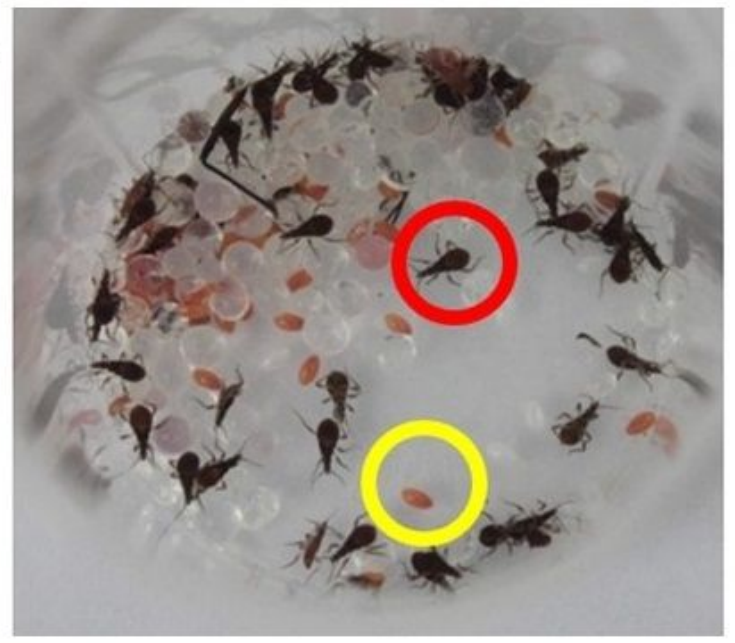

B

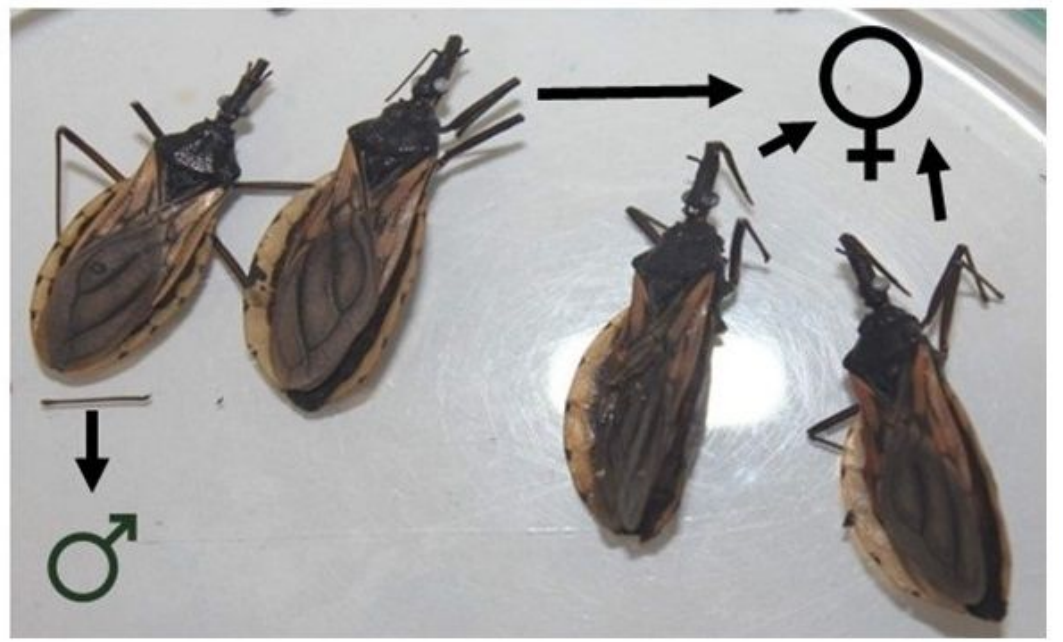

Figure 9 
A. Eggs (yellow circle) and nymphs (red circle); B. One male and three female specimens of Triatoma williami collected in Barra do Garças, Mato Grosso, Brazil, in 2019.

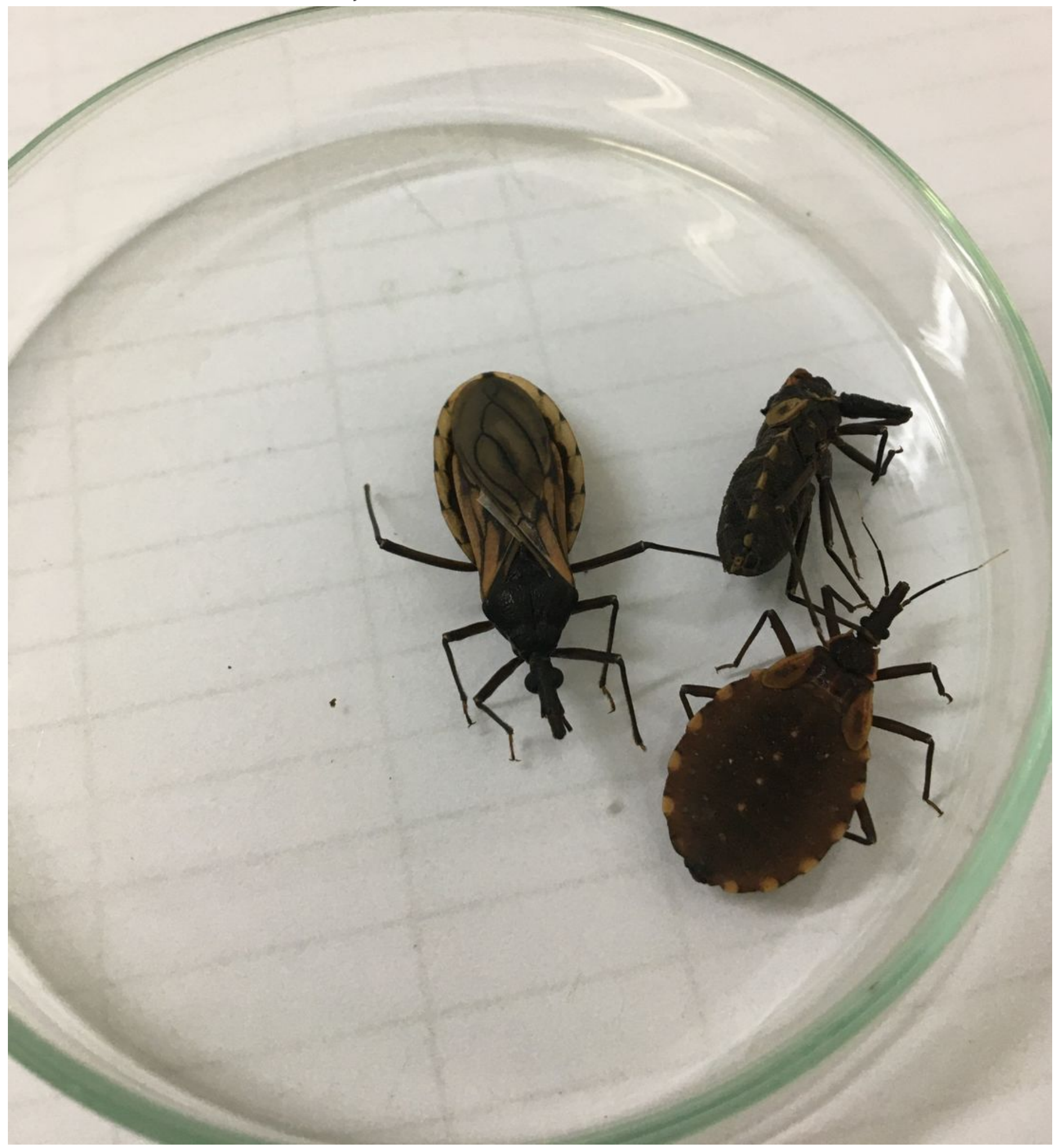

Figure 10

The specimens of Triatoma williami sampled after the residual chemical control in Barra do Garças, Mato Grosso, Brazil, in 2021. 